\title{
Optimization of production technology of pea (Pisum sativum L.) enriched plant growth Rhizobacteria
}

Adil Khan ${ }^{1 *}$, Muhammad $\mathrm{Ali}^{2}$, Sajid Khan ${ }^{3}$, Waqar Karim ${ }^{1}$ and Ismail

$\mathrm{Khan}^{4}$

1. Institute of Horticultural Sciences, University of Agriculture Faisalabad-Pakistan

2. College of Horticulture, Northwest A\&F University, Yangling 712100 Shaanxi-China

3. Department of Management Sciences, The University of Swabi-Pakistan

4. College of Water Resources, Shenyang Agricultural University-China

*Corresponding author's email: adilapx@ hotmail.com

Citation

Adil Khan, Muhammad Ali, Sajid Khan, Waqar Karim and Ismail Khan. Optimization of production technology of pea (Pisum sativum L.) enriched plant growth Rhizobacteria, Pure and Applied Biology. Vol. 8, Issue 1, pp278-287. http://dx.doi.org/10.19045/bspab.2018.700186

\begin{tabular}{llll}
\hline \hline Received: 05/08/18 & Revised: 07/11/18 & Accepted: 10/11/18 & Online First: 13/11/18 \\
\hline \hline
\end{tabular}

\section{Abstract}

Pea (Pisum sativum L.) having capability to harbor plant growth promoting rhizobacteria.The experiment was conducted to examine, the effect of plant growth promoting rhizobacteria (PGPRs) single or in addition with L-tryptophan, a precursor of auxin on production of Pisum sativum L. Experiment was conducted at the vegetable area, Delma Island United Arab Emirates. Seeds of Pisum sativum L.) cultivars viz. Meteor, Alina Pak, Climax and Pea- 2009 were treated with FF-34 (Pantoea sp.), (Burkholderia phytofirmans), FF34+L-Tryptophan, PsJN PsJN+L-Tryptophan, water (positive control) whereas untreated seeds assisted as control. Data were collected concerning various parameters such as plant emergence percentage, plant height, branches number plant ${ }^{-1}$, chlorophyll content, days to $1^{\text {st }}$ flowering, days from flowering to $1^{\text {st }}$ pod maturity, number of pods per plant, pod length, seeds number pod $^{-1}$, fresh and weight of dry plant, harvest index and hundred seed weight. Pea varieties Pea-2009 and Climax excelled over all other varieties for some traits. Among seed treatments FF-34 exhibited better results for maximum parameters. Results signify the role of PGPRs in Pea growth and productivity.

Keywords: Inoculation; L-tryptophan; Pisum sativum; Pods maturity; Rhizobacteria

\section{Introduction}

Pea ranks $4^{\text {th }}$ in grain legumes (soybean, groundnuts and French beans) in the biosphere on the basis of production (441.53 thousand tons). The fresh Pisum sativum L. is grown on 2.266 million hectares round the earth with average production of 8.1 tons/ hectares and 18.9 million tons respectively, while production of dry of the globe is reduced per annum by average of $1.8 \%$. In 2011 from all over the globe dry pea spreads were 4.8 million metric tons [1]. Joseph et al.
[2] reported that commercially, dry peas are cultivated in more or less than 100 countries around the world, but the yield is only rigorous in countries such as Canada, China and Russia.

Pea is a flexible crop holding high adaptability to the thrilling circumstances of temperature, scarcity, tolerate basic conditions of soil and possess high potential of natural nitrogen fixation. Therefore, introducing and assessment of improved legume verities perform better in rain-fed 
including irrigated situations and it improvement for production and its contributing performance are of crucial importance to get self-capability in different pulses [3]. Aslam et al. [4] described that developmental process and yield of pea crops are greatly affected by numerous aspects such as ecological circumstances, soil type, practices of irrigation, plant density, planting pattern, sowing date, seed rate, diseases, insect pests, weeds control and preparation of seed bed. Whereas, Monreal [5] proved from there experiment that rotation of crops and time of harvesting are also important aspect for better yield and production of legumes. PGPRs are beneficial microscopic bacteria that inhabit plant roots and increase development of plant utilizing extensive range of components such as root exudates [6, 7]. Cakmakci et al. [8] observed that PGPRs microbes increases the convenience of plant nutrition and lesser the requirements for artificial manures. Nitrogen altering and phosphorus solubilize minute microbes may be necessary for plant nourishment by intensifying nitrogen and phosphorus uptake by the plants $[9,10]$. These PGPRs has used to increase growth as well as for resistance and abiotic stress capability of pea crops. Cakmakci [11] outlined that these can be used through diverse methods in which seed inoculation is the most well-known. Rhizosphere is the narrow region of microbial activity and refuge a significant measures for beneficial activities of plant roots. This zone of soil is rich in nutrients because fourthly percent loss of sugars from the roots occur here. Rhizospheric microbes have the capability to use the important materials secreted from roots as nutritional sources. Amongst all rhizospheric microbes, Aspergillus kind have-been classified to transport different types of metabolites, which are valued in the biological mechanism of chick pea root decay [12]. [13] reported that Aspergillus spp. have the ability to solubilize phosphates, which are insoluble directly in soil, to solubilized forms by releasing natural acids, such as, lactic, glycolic, formic, propionic, fumaric, acetic and succinic acids. Khan et al. [14] described that Aspergillus awamori and Aspergillus niger usage brings about 58\% and $85 \%$ increases in the production of tomato plants, respectively. Siddiqui and Akhtar [15] reported that use of $A$. awamori deeply helps in development of plant by increasing NPK uptake and production of chlorophyll. Additionally, it decreases root decay collar rots in chickpea. It is also cleared from literatures of Nair and Burke [16] that inoculation of Aspergillus awamori provides phenyl acidic eroding, phenoxy acidic corroding and phenyl-ethanol, while which may decreased the disorder significantly in harvested plants [17]. Harman et al, [18] Concluded from there results that Hypocrea lixii has been supposed for its biological control measure against a few plants diseases organism upon different components such as enzymatic hydrolysis, antibiosis, rivalry and myco-parasitism. In addition, Yedidia et al, [19] reported that these organisms advances plants development and take part in resistance systemically in various plants. Different biological nitrogen fixer have been used by scientists which helps in better production pea crops. Naveed et al, [20, 21] used Burkholderia phytofirmans and Pantoea spp. FF-34 before in Zea mays however they are not applied to peas. So, this trail has been conducted to evaluate the impact of these two plant promoting rhizo bacteria, single or in addition with L-tryptophan on development and production of four different pea cultivars. The main objective of our study is to find out which strain of PGPRs is more effective for pea seed inoculation and examine the response of different pea cultivars inoculation with PGPRs. 


\section{Materials and methods}

The experiment was conducted at Vegetable Seed Area, Delma Island United Arab Emirates 2017-2018, to study the Pea growth, development and production followed by seed inoculation with plant growth promoting rhizobacteria. Experiment was lead according to randomized complete block (RCBD) design under factorial arrangement. Three repetitions of each treatment was conducted. Seed of four pea varieties (Meteor, Alina Pak, Climax, Pea-2009) were sown on raised beds at 4 inch plant-to-plant spacing. These varieties were obtained from University of Agriculture Faisalabad. CAN, SSP, NPK and SOP were used as the source of nitrogen, phosphorus, potash.

In $1^{\text {st }}$ process we treated seed with bacteria FF-34 and PsJN and used 60ml water for water socking then seed was treating for 30 minutes in $60 \mathrm{ml}$ solution $\left(\mathrm{T}_{0}=\right.$ Untreated seeds (-ve Control), $\mathrm{T}_{1}=$ Water soaking (+ve Control), $\mathrm{T}_{2}=\mathrm{FF}-34, \mathrm{~T}_{3}=\mathrm{FF}-34+\mathrm{L}-$ trytophan, $\mathrm{T}_{4}=$ PsJN, $\mathrm{T}_{5}=\mathrm{PsJN}+\mathrm{L}$ tryptophan). After treating seeds then sown in 4 inch apart in field (PXP) distance. The seeds of four selected pea varieties were sown on raised beds. The crop was sown on December, 2017. In each planting, 4-5 seeds at depth of 1 inch per hole were sown in ridge at (4 inch) spacing. Field was watered directly after sowing of crop and afterward as per crop requirements. After the emergence of two true leaves, only one seedling were kept and the other were removed for vigorous growth. Crops were supplied with NPK at the rate of 40:40:25 $\mathrm{kg}$ per acre. Nitrogen being provided in three splits, firstly at land preparation, secondly at flowering stage while thirdly at the period of pod filling. Cultural practices i.e. weeding, earthling up were same for all trails. Three plants having good vigor and health of each variety were selected for further study from each experimental unit. Harvesting was completed at time when the lower 4-5 pods of plant were dried out. Harvested seeds were subjected to quality analysis. Data were recorded for the following attributes viz: emergence (7-8 days after sowing), height of plant $(\mathrm{cm})$, branches number plant $^{-1}$, chlorophylls content $(\mu \mathrm{g} / \mathrm{mg})$, fresh weight of plant $(\mathrm{g})$, dry weight of plant $(\mathrm{g})$, days to first flowering, days to first pod maturity from flowering, pods number plant ${ }^{-1}$, length of pod $(\mathrm{cm})$, weight of pod $(\mathrm{g})$, number of seeds pod ${ }^{-1}$ and 100 seed weight $(\mathrm{g})$.

\section{Statistical analysis}

Data were statistically analyzed using Fisher's analysis of variance technique [22]. The treatment means were compared by using Tukey's test at 5\% probability level.

\section{Results and discussion}

Emergence (\%)

Result of data regarding emergence percentage shown significant differences among treatments and non-significant in varieties. The interaction of both varieties and treatments were also non-significant (Table 1). It is proved from the results that maximum emergence percentage was observed in seeds treated with FF-34 (91.81 $\%)$ followed by FF-34+L-Tryptophan (85.37 $\%)$ statistically at par with PsJN (83.37\%), PsJN + L-Tryptophan (83.81\%) and $\mathrm{H}_{2 \mathrm{O}}$ soaking $(81.43 \%)$. While, less emergence \% was noted in control $(67.31 \%)$. It is concluded from results that variety of pea Alina Pak showed maximum emergence (83.45\%) followed by Pea-2009 (82.41\%), Climax (82.29 \%), and Meteor (80.58 \%) (Table 2). Our findings show similarity with results of Kala et al, [23] on the growth and yield of Horsgram (Dolichos biflours L.) in the field. They observed more germination in field pea when treated with PGPRs.

\section{Plant height $(\mathbf{c m})$}

Data in term of plant height shows significant differences in various varieties and treatments. Although there interaction of varieties and treatments were also significant (Table 1). It is clear from conclusion that 
plants collected from seeds treated with FF34 gave more plant height $(80.75 \mathrm{~cm})$ that was statistically at par with FF-34+L-Tryptophan (79.87cm), PsJN (78cm), PsJN +LTryptophan $(76.87 \mathrm{~cm})$ and $\mathrm{H}_{2} \mathrm{O}$ soaking $(71 \mathrm{~cm})$ while, less plant height was observed in control $(59.50 \mathrm{~cm})$. It was noticed that variety of pea Climax gives maximum plant height $(75.50 \mathrm{~cm})$ followed by Pea-2009 $(74.79 \mathrm{~cm})$, Alina pak $(74.33 \mathrm{~cm})$ and Meteor (72.70) (Table 2). Our findings shows comparison with results of Rather et al, [24] they perceived more plant height in field pea when treated with PGPRs.

\section{Number of branches plant ${ }^{-1}$}

Data regarding no. of branches per plant was analyzed using ANOVA technique which shows substantial differences among different varieties and treatments, while there interaction effect were non-significant (Table 1). It is cleared from results that plants grown from seeds treated with FF-34 produced more no. of branches per plant (16.0). While, less number of branches (9.5) were noted in plants grown from untreated seeds i.e. negative control. Hence concluded that pea variety Climax produced maximum number of branches plant ${ }^{-1}$ (14.87). While Meteor plants had the least number of branches (10.91) (Table 2). Our results shows similarity with conclusions of Erman et al, [25] who reported more number of branches in pea when treated with Rhizobium as compared with control.

\section{Chlorophyll content $(\mu \mathrm{g} / \mathrm{mg})$}

Data regarding chlorophyll contents shows significant differences among varieties and treatments. While there interaction effect shows non-significant results (Table 1). It is cleared from our results that treatment FF-34 gave concentrated chlorophyll content $(2.18$ $\mathrm{mg})$, FF-34+L-Tryptophan (2.075 $\mathrm{mg})$ statistically at par with PsJN (1.19 mg) and PsJN +L-Tryptophan (1.82 $\mathrm{mg})$ and also for water soaking $(1.135 \mathrm{mg})$. While, minimum chlorophyll contents were observed in control $(1.13 \mathrm{mg})$. It is obvious from the results that pea variety Alina pak showed maximum chlorophyll content $(2.008 \mathrm{mg})$ followed by Climax (1.87 mg), Pea-2009 (1.75 mg) and Meteor (1.64 mg) (Table 2). Our conclusions shows resemblance with findings of Mishra et al, [26], they observed field pea showed more chlorophyll contents when treated with different levels of PGPRs.

\section{Days to first flowering}

Analysis of the data regarding days to first flowering exposed negative effects for variety and shows substantial results for treatment. Similarly, the interaction effect was negative for both (Table 1). It is evident from the results that days to first flowering were greater in plants collected from untreated seeds (67.37) statistically at per with the results of PsJN (55.50), FF-34 (56.66), FF-34+L-Tryptophan (55.6), and PsJN+L-Tryptophan (54.5). Whereas, less days to first flowering was recorded in plants obtained from $\mathrm{H}_{2} \mathrm{O}$ soaking (53.18). It was observed that variety Climax gave maximum days to first flowering (57.66) followed by Pea-2009 (57.62) statistically similar with Alina Pak (56.87) and Meteor (56.37). (Table 2). Our results are in a line with the findings of Namvar \& Sharifi [27] who observed chickpea gave maximum days to first flowering when treated with different levels of PGPR.

Days from flowering to first pod maturity Statistical analysis of the data obtained for days from flowering to first pod maturity revealed non-significant differences among treatments. Also, the interaction effect of treatment $\times$ variety was non-significant (Table 1). It is obvious from the results that days from flowering to first pod maturity were minimum in plants obtained from FF-34 (23.31days) followed by PsJN+LTryptophan (25.62days) statistically at par with FF-34+L-Tryptophan (27.62days), PsJN (27.68days) and water soaking (29.88 days). Whereas, maximum days from 
flowering to first pod maturity was recorded in control (29.12 days). It was also observed that Pea-2009 (27.54days) took maximum days from flowering to first pod maturity followed by Climax (27.45days), Meteor (27.05days) and Alina Pak (26.79 days) (Table 2). Our results shows similarity with findings of Namvar et al, [28], who reported minimum days from flowering to pod maturity in chickpea seeds treated with different levels of PGPRs.

\section{Number of pods plant ${ }^{-1}$}

Analysis of variance showed positive results in term of pod number per plant between various variety and treatments. While, there interaction were non-significant (Table 1). It was perceived that treatment FF-34 gave greater no. of pods per plant (15.2) followed by FF-34+L Tryptophan (13.433), PsJN (13.0), PsJN+L-Tryptophan (12.180) and $\mathrm{H}_{2 \mathrm{O}}$ soaking (11.30). Whereas, less no. of pods per each plant were observed in untreated (10.37). Similarly it was concluded that variety of pea Climax produced maximum number of pods plant ${ }^{-1}$ (14.54) followed by Pea-2009 (13.20), Alina pak (11.91) and Meteor (10.70) (Table 2). Our conclusions are similar with the findings of Begum et al, [29] they experienced more number of Pea pods per plant when seeds were treated with different PGPRs.

\section{Pod length (cm)}

Statistical analysis of data regarding pod length revealed positive differences among varieties and treatments, while there interaction effect were non-significant (Table 1). It is obvious from results that plants seeds treated with FF-34 produced pods of more length $(8.1 \mathrm{~cm})$ followed by $\mathrm{FF}-34+\mathrm{L}-$ Tryptophan $(7.9 \mathrm{~cm})$, and PsJN $(7.8 \mathrm{~cm})$; all were statistically at par with each other. While, least pod length $(6.4 \mathrm{~cm})$ was recorded in plants grown from untreated seeds i.e. negative. It was observed that pea variety produced Pea-2009 pods of maximum length $(7.84 \mathrm{~cm})$, but was statistically at par with Climax $(7.7 \mathrm{~cm})$. Meteor produced pods of smallest size i.e. $7.45 \mathrm{~cm}$ (Table. 2). These findings are confirmed by the findings of Rather et al, [24] who reported increased in pod length when Pea seeds were treated with different PGPRs as compared to untreated seed. Our results are partially in accordance with the result of Naveed et al, [21] who recorded increase in length of maize plant due to FF-34 in comparison with plant grown from non-inoculated seeds.

\section{Pod weight $(\mathrm{g})$}

Statistical analysis regarding pod weight revealed significant difference among treatment and varieties. While, there interaction were observed as non-significant (Table 1). It is obvious from the consequences that pods obtained from the seeds treated with FF-34 (1.57g) gave maximum weight followed by FF-34+LTryptophan $(1.49 \mathrm{~g})$ that was statistically at par with PsJN (1.38g), PsJN+L-Tryptophan $(1.30 \mathrm{~g})$ and control (1.30g). Whereas, Minimum pod weight was observed in water soaking $(1.26 \mathrm{~g})$. It was noted that variety Pea-2009 showed greater pod weight (1.51g) followed by Climax $(1.42 \mathrm{~g})$, Alina Pak $(1.34 \mathrm{~g})$ and Meteor (1.26g) (Table 2). Our conclusion shows resemblance with the findings of Maleki et al, [30], they got maximum pod weight in chickpea treated with Rhizobium inoculation.

\section{Fresh weight of plant (g)}

Analysis in term of data regarding fresh weight revealed substantial difference of treatments and varieties. Whereas, there interaction were non-significant (Table 1). FF-34 treated seeds gives maximum fresh weight i.e. $27.12 / \mathrm{g}$, but was statistically at par with FF-34+L-Tryptophan (25.81/g). While, less fresh weight was calculated in untreated $(16.50 / \mathrm{g})$. Similarly it was noted that pea variety Climax presented maximum fresh bearing of plant $(25.16 / \mathrm{g})$ followed by Pea2009 (24.0 g), which was statistically at par with Climax and Alina Pak (22.25/g). The 
least value of plant fresh weight $21.58 / \mathrm{g}$ was recorded in Meteor. (Table 2). Geneva et al, [31] observed increased in pea plant weight due to PGPRs, which strengthen our results.

\section{Dry weight of plant (g)}

Seedling of inoculated (treated seeds) and uninoculated (untreated seeds) plants were harvested after three weeks of sowing to record any difference in fresh weight of plant. Substantial difference was obtained regarding plant dry weight in different varieties and treatment. Whereas, there interaction shows non-significant effect (Table 1). A perusal of results revealed that plants collected from FF-34 treated seeds exhibited maximum dry weight $(5.45 / \mathrm{g})$, which was statistically at par with FF-34+LTryptophan (5.21/g), PsJN (5.0/g), PsJN+LTryptophan (4.95/g). Whereas, less dry weight of plants were obtained in untreated $(2.66 / \mathrm{g})$ that showed non-significant difference form $\mathrm{H}_{2} \mathrm{O}$ soaking treatment (4.84/g). Results also investigated improbity of pea variety Pea-2009 that produced maximum dry weight of plant $(4.87 / \mathrm{g})$ followed by Climax (4.76/g), Alina Pak $(4.65 / \mathrm{g})$; all were statistically at par. Meteor exhibited the least dry weight of plant $(4.51 / \mathrm{g})$ (Table 2). These results shows similarity with findings of Solaiman and Rabbani [32] who recorded more plant dry weight due to the treatment with different PGPRs.

\section{Hundred seed weight (g)}

Substantial conclusion were calculated for hundred seed weight in different pea varieties. Whereas, there interaction shows non-significant results (Table 1). It was detected that seeds treated with FF-34 produced plants with extreme hundred seed weight $(20.84 / \mathrm{g})$ statistically at par with FF34+L-Tryptophan (18.68/g), PsJN (16.68/g), PsJN +L-Tryptophan (15.43/g) and $\mathrm{H}_{20}$ soaking (12.25g). Whereas, lowest hundred seed weight were observed in untreated seeds $(10.75 / g)$. It was also observed that pea variety Pea-2009 showed greater hundred seed weight $(18.20 / \mathrm{g})$ then by Climax $(16.33 / \mathrm{g})$, Alina-pak (14.91/g) and Meteor (13.62/g) (Table 2). Our conclusions shows resemblance with findings of Geneva et al, [31], they observed maximum hundred seed weight when Chickpea seeds treated with PGPRs.

\section{Number of seeds pod $^{-1}$}

Data regarding no. of seeds pod $^{-1}$ among various treatments and varieties shows significant result. While, there interaction was observed as non-significant (Table 1). Similarly, plants collected from seeds treated with PSJN (7.5) gave greater number of seeds pod $^{-1}$ followed by FF-34 (7.461), PsJN+LTryptophan (7.1), FF-34+L-Tryptophan (6.8) and $\mathrm{H}_{2} \mathrm{O}$ soaking (6) whereas, less number of seeds pod $^{-1}$ were observed in untreated seeds (6.37) (Table 4.8). Similarly pea variety Pea2009 showed greater number of seeds pod $^{-1}$ (7.20) then Climax (7.08), Alina Pak (6.94) and Meteor (6.77) (Table 2). Our conclusions are similar with results of Ahmed et al, [33] showed more number of seeds per plant when treated with Rhizobium inoculation.

\section{Seed yield plant $^{-1}(\mathrm{~g})$}

Analysis of variance of the data obtained for seed yield/plant revealed significant differences for variety and treatments. Also, the interaction effect of treatment $\times$ variety was non-significant (Table 1). It is clear from the results that maximum seed yield/plant was obtained from FF-34 (34.9g) followed by FF34+L-Tryptophan (33.7g), PsJN (32.3g) statistically similar with PsJN+L-Tryptophan (30.8g) and $\mathrm{H}_{20}$ soaking (30.2g). Whereas, lowest seed yield/plant was recorded in untreated $(28.1 \mathrm{~g})$. While pea variety Pea-2009 showed maximum seed yield plant $^{-1}(33.7 \mathrm{~g})$ followed by Climax (32.4g), Alina pak (31.1g) and Meteor (29.5g) (Table 2). Our results for seed yield per plant were statistically at par with the results of Zahir et al, [34] in mung bean when treated with PGPRs. Our results are similar with the findings of Shaharoona et al. [35], they observed maximum yield in wheat treated with Rhizobium inoculation. 
Table 1. Shows mean values for different cultivars of pea

\begin{tabular}{|c|c|c|c|c|c|c|c|c|c|c|c|c|c|c|}
\hline Cultivars & $\begin{array}{l}\text { Emergenc } \\
\text { e \% }\end{array}$ & $\begin{array}{l}\text { Plant } \\
\text { height } \\
\text { (cm) }\end{array}$ & $\begin{array}{l}\text { Branches } \\
\text { plant }^{-1}\end{array}$ & $\begin{array}{l}\text { Chlorophyll } \\
\text { Content } \\
(\mu \mathrm{g} / \mathrm{mg}) \\
\end{array}$ & $\begin{array}{l}\text { First } \\
\text { flowering }\end{array}$ & $\begin{array}{l}\text { Pod } \\
\text { maturity }\end{array}$ & $\begin{array}{l}\text { Pods } \\
\text { plant }^{-1}\end{array}$ & $\begin{array}{l}\text { Pod } \\
\text { Length } \\
(\mathrm{cm}) \\
\end{array}$ & $\begin{array}{l}\text { Pod } \\
\text { weight } \\
\text { (g) }\end{array}$ & $\begin{array}{l}\text { Plant } \\
\text { fresh } \\
\text { weight }(g)\end{array}$ & $\begin{array}{l}\text { Plant } \\
\text { Dry weight } \\
\text { (g) }\end{array}$ & $\begin{array}{l}\text { 100 Seeds } \\
\text { Weight } \\
\text { (g) }\end{array}$ & $\begin{array}{l}\text { Seeds } \\
\text { pod }^{-1}\end{array}$ & $\begin{array}{l}\text { Yield } \\
\text { palnt }^{-1}\end{array}$ \\
\hline Alina Pak & $83.4 \mathrm{~A}$ & $74.3 \mathrm{~B}$ & $14.87 \mathrm{~A}$ & $2.0 \mathrm{~A}$ & $56.8 \mathrm{~A}$ & $26.7 \mathrm{~A}$ & $11.9 \mathrm{C}$ & $7.6 \mathrm{BC}$ & $1.3 \mathrm{C}$ & $22.25 \mathrm{~B}$ & $4.6 \mathrm{AB}$ & $14.9 \mathrm{C}$ & $6.9 \mathrm{~A}$ & $31.1 \mathrm{C}$ \\
\hline Climax & $82.2 \mathrm{AB}$ & $75.5 \mathrm{~A}$ & $14.04 \mathrm{~B}$ & $1.8 \mathrm{~B}$ & $57.6 \mathrm{~A}$ & $27.4 \mathrm{~A}$ & $14.5 \mathrm{~A}$ & $7.7 \mathrm{AB}$ & $1.4 \mathrm{~B}$ & 0.014 & $4.7 \mathrm{AB}$ & $16.3 \mathrm{~B}$ & $7.0 \mathrm{~A}$ & $32.4 \mathrm{~B}$ \\
\hline Pea-2009 & $82.4 \mathrm{AB}$ & $74.7 \mathrm{AB}$ & $12.33 \mathrm{C}$ & $1.7 \mathrm{C}$ & $57.6 \mathrm{~A}$ & $27.5 \mathrm{~A}$ & $13.2 \mathrm{~B}$ & $7.8 \mathrm{~A}$ & $1,5 \mathrm{~A}$ & $24.0 \mathrm{AB}$ & $4.8 \mathrm{~A}$ & $18.2 \mathrm{~A}$ & $7.2 \mathrm{~A}$ & $33.7 \mathrm{~A}$ \\
\hline Meteor & $80.5 \mathrm{~B}$ & $72.7 \mathrm{C}$ & $10.91 \mathrm{D}$ & $1.6 \mathrm{D}$ & $56.3 \mathrm{~A}$ & $27.0 \mathrm{~A}$ & $10.7 \mathrm{D}$ & $7.4 \mathrm{C}$ & $1.2 \mathrm{D}$ & $21.58 \mathrm{C}$ & $4.5 \mathrm{~B}$ & $13.6 \mathrm{D}$ & $6.7 \mathrm{~A}$ & $29.5 \mathrm{D}$ \\
\hline LSD & NS & 0.4792 & 0.2920 & 0.0252 & 1.7881 & 0.4455 & 0.2750 & 0.0768 & 0.012 & 0.5131 & $0.1123 \mathrm{~A}$ & 0.4748 & 0.2109 & 0.21 \\
\hline
\end{tabular}

Non-significant interaction was found in all cultivars.

Any two means not sharing a common letter are significantly different at 5\% probability level for each factor as well as interaction

Table 2. Shows mean values for different treatments of pea

\begin{tabular}{|c|c|c|c|c|c|c|c|c|c|c|c|c|c|c|}
\hline Treatments & $\begin{array}{c}\text { Emergence } \\
\%\end{array}$ & $\begin{array}{c}\text { Plant } \\
\text { height } \\
(\mathrm{cm})\end{array}$ & $\begin{array}{c}\text { Branches } \\
\text { plant }^{-1}\end{array}$ & $\begin{array}{c}\text { Chlorophyll } \\
\text { content } \\
\text { ( } \mathrm{gg} / \mathrm{mg})\end{array}$ & $\begin{array}{c}\text { First } \\
\text { flowering }\end{array}$ & $\begin{array}{c}\text { Pod } \\
\text { maturity }\end{array}$ & $\begin{array}{c}\text { Pods } \\
\text { plant }^{-1}\end{array}$ & $\begin{array}{r}\text { Pod } \\
\text { length }(c\end{array}$ & $\begin{array}{c}\text { Pod } \\
\text { weight }\end{array}$ & $\begin{array}{c}\text { Plant } \\
\text { fresh } \\
\text { weight }(\mathrm{g})\end{array}$ & $\begin{array}{l}\text { Plant dry } \\
\text { weight (g) }\end{array}$ & $\begin{array}{c}100 \text { seeds } \\
\text { weight }(\mathrm{g})\end{array}$ & $\begin{array}{l}\text { Seeds } \\
\text { pod }^{-1}\end{array}$ & $\begin{array}{c}\text { Yield } \\
\text { palnt }^{-1}\end{array}$ \\
\hline -ve control & $67.3 \mathrm{D}$ & $59.5 \mathrm{D}$ & $9.56 \mathrm{D}$ & $1.1 \mathrm{E}$ & $67.3 \mathrm{~A}$ & $29.8 \mathrm{~A}$ & $10.3 \mathrm{E}$ & $6.4 \mathrm{D}$ & $1.3 \mathrm{D}$ & $16.5 \mathrm{D}$ & $2.6 \mathrm{C}$ & $10.7 \mathrm{D}$ & $6.3 \mathrm{C}$ & $28.1 \mathrm{E}$ \\
\hline +ve control & $81.4 \mathrm{C}$ & $71 \mathrm{C}$ & $12.25 \mathrm{C}$ & $1.6 \mathrm{D}$ & $53.1 \mathrm{~B}$ & $23.3 \mathrm{D}$ & $11.3 \mathrm{DE}$ & $7.7 \mathrm{C}$ & $1.2 \mathrm{D}$ & $22.1 \mathrm{C}$ & $4.8 \mathrm{C}$ & $12.2 \mathrm{D}$ & $6.6 \mathrm{BC}$ & $30.2 \mathrm{D}$ \\
\hline FF-34 & $91.8 \mathrm{~A}$ & $80.7 \mathrm{~A}$ & $16.00 \mathrm{~A}$ & $2.1 \mathrm{~A}$ & $56.5 \mathrm{~B}$ & $23.3 \mathrm{D}$ & $15.2 \mathrm{~A}$ & $8.1 \mathrm{~A}$ & $1.5 \mathrm{~A}$ & $27.1 \mathrm{~A}$ & $5.4 \mathrm{~A}$ & $20.8 \mathrm{~A}$ & $7.4 \mathrm{~A}$ & $34.9 \mathrm{~A}$ \\
\hline $\begin{array}{l}\text { FF-34+L } \\
\text { Tryptophan }\end{array}$ & $85.3 \mathrm{~B}$ & $79.8 \mathrm{~A}$ & $13.93 \mathrm{~B}$ & $2.0 \mathrm{~B}$ & $55.6 \mathrm{~B}$ & $27.6 \mathrm{~B}$ & $13.4 \mathrm{~B}$ & $7.9 \mathrm{AB}$ & $1.4 \mathrm{~B}$ & $25.8 \mathrm{AB}$ & $5.2 \mathrm{AB}$ & $18.6 \mathrm{~B}$ & $6.8 \mathrm{ABC}$ & $33.7 \mathrm{~B}$ \\
\hline PsJN & $83.3 \mathrm{BC}$ & $78 \mathrm{~B}$ & $13.56 \mathrm{~B}$ & $1.9 \mathrm{C}$ & $55.5 \mathrm{~B}$ & $27.6 \mathrm{~B}$ & $13.0 \mathrm{BC}$ & $7.8 \mathrm{ABC}$ & $1.3 \mathrm{C}$ & $24.9 \mathrm{~B}$ & $5.0 \mathrm{AB}$ & $16.6 \mathrm{C}$ & $7.5 \mathrm{~A}$ & $32.3 \mathrm{C}$ \\
\hline $\begin{array}{l}\text { PsJN+L } \\
\text { Tryptophan }\end{array}$ & $83.8 \mathrm{BC}$ & $76.8 \mathrm{~B}$ & $12.93 \mathrm{BC}$ & $1.8 \mathrm{D}$ & $515 \mathrm{P}$ & $25.6 \mathrm{~B}$ & $12.1 \mathrm{CD}$ & $7.8 \mathrm{BC}$ & $1.3 \mathrm{D}$ & $24.0 \mathrm{BC}$ & $4.9 \mathrm{~B}$ & $15.4 \mathrm{C}$ & $7.1 \mathrm{AB}$ & $30.8 \mathrm{D}$ \\
\hline LSD & 1.29 & 0.3913 & 0.3576 & 0.0309 & 1.4600 & 0.5456 & 0.3369 & 0.0941 & 0.014 & 0.6281 & 0.1376 & 0.5815 & 0.2583 & 0.26 \\
\hline
\end{tabular}

Any two means not sharing a common letter are significantly different at $5 \%$ probability level for each factor as well as interaction 


\section{Conclusion}

It is concluded from all results that seeds treated with FF-32 exhibited better results for all parameters except number of seed pod $^{-1}$ which was higher for PsJN. Basis of this experiment we concluded that plant growth promoting rhizobateria (PGPRs) have significant impact on pea production.

\section{Authors' contributions}

Conceived and designed the experiments: $\mathrm{M}$ Ali \& A Khan, Performed the experiments: A Khan, Analyzed the data: S Khan, Contributed reagents/ materials/ analysis tools: I Khan, Wrote the paper: M Ali, A Khan \& W Karim, Equal contributors in the paper: A Khan \& M Ali.

\section{References}

1. FAOSTAT. (2012). Crops country data. http: faostat.fao.org site 339 default.aspx.

2. Joseph PJ, Brester GW \& Smith VH (2014). Dry peas trends in production, trade and price. Agricultural Marketing Policy Center. Am J Agric Econ 96(2): 542-556.

3. Khan A, Bari A, Khan S, Shah NH and Zada I (2010). Performance of cowpea genotype at higher altitude of NWFP. Pak $J$ Bot 42(4): 2291-2296.

4. Aslam M, Mahmood IA, Sultan T and Ahmad S (2000). Inoculation approach to legume crops and their production assesment in pakistan. A review, Pak $J$ Biol Sci 10(3): 193-195.

5. Monreal AR (1988). The effect of ridging on the performance of pigeon pea in the low upland tropics. U.K, J Agric Sci 104(1): 243-245.

6. Ashrafuzzaman M, Hossen FA, Ismail MR, Hoque MA, Islam MZ, Shahidullah SM and Meon S (2009). Efficiency of plant growth promoting rhizobacteria (PGPR) for the enhancement of rice growth. Afr J Biotechnol 8(5): 12471252.

7. Faheem M, Ali M, Ullah N, Alam M, Khan HU, Anwar M (2016). Antitumour activity of essential oil of rosemary by potato disc method. Biol Diversity and Conser 9(1): 44-48.

8. Cakmakci R, Donmez MF and Erdogan U (2007a). The effect of plant growth promoting rhizobacteria on barley seedling growth, nutrient uptake, some soil properties and bacterial counts. Turk J Agric For 31(45): 189-199.

9. Cakmakci R, Donmez F, Aydin A and Sahin F (2006). Growth promotion of plants by plant growth-promoting rhizobacteria under greenhouse and two different field soil conditions. Soil Biol Biochem 38(3): 1482-1487.

10. Ali M, Khattak AM, Ullah $\mathrm{K}$ and Ibrahim M (2015), Performance of Exotic Tulip Cultivars under AgroClimatic Conditions of Peshawar. $J$ of Bio resource Manag 2(3): 1-8.

11. Cakmakci R, Erat M, Erdogan U and Donmez MF (2007b). The influence of plant growth-promoting rhizobacteria on growth and enzyme activities in wheat and spinach plants. J Plant Nutri Soil Sci 170(65): 288-295.

12. Akhtar MS and Siddiqui ZA (2006). Effects of phosphate solubilizing microorganisms on the growth and rootrot disease complex of chickpea. Mycol Phytopathol 40(55): 246-254.

13. Rashid M, Khalil S, Ayub N, Alam S and Latif F (2004). Organic acids production and phosphate solubilization by phosphate solubilizing microorganisms (PSM) under in vitro conditions. Pak $J$ Biol Sci 7(2): 187-196.

14. Khan, MR and Khan SM (2001). Biomanagement of Fusarium wilt of tomato by the soil application of certain phosphate solubilizing microorganisms. Int J Pest Manage 47(89): 227-231.

15. Siddiqui ZA and Akhtar MS (2007). Biocontrol of a chickpea root rot disease complex. J Plant Pathol 89(9): 67-77. 
16. Nair, MG and Burke BA (1988). A new fatty acid, methyl ester and other biologically active compounds from Aspergillus niger. Phyto chem 27(21): 3169-3373.

17. Palakshappa, MG, Kulkarni S and Hedge RK (1989). Effect of organic amendment on the survival activity of Sclerotium rolfsii. A causal agent of the foot rot of berelvine. Mysore J Agric Sci 23(87): 332-336.

18. Harman, GE, Howell CR, Viterbo A, Chet I and Lorito M (2004). Trichoderma species opportunistic: Avirulent plant symbionts. Nature Rev 2(12): 43-56.

19. Yedidia, I, Benhamou N and Chet I 1999. Induction of defense response in cucumber plants (Cucumis sativus L.) by the biocontrol agent Trichoderma harzianum. Appl Environ Microbiol 65(3): 1061-1070.

20. Naveed, M, Mitter B, Yousaf S, Pastar M, Afzal M and Sessitsch A (2014). The endophyte Enterobacter sp. FD17: A maize growth enhancer selected based on rigorous testing of plant beneficial traits and colonization characteristics. Bio Fert Soils 50(2): 249-262.

21. Naveed M, Qureshi MA, Zahir ZA, Hussain MB, Sessitsch A and Mitter B (2015). L-Tryptophan - dependent biosynthesis of indole-3-acetic acid (IAA) improves plant growth and colonization of maize by Burkholderia phytofirmans PsJN. Annals Microbiol 65(3): 1381-1389.

22. Steel RGD, Torrie JH and Dickey D (1997). Principles and Procedure of Statistics. A Biometrical Approach, 3rd Ed. McGraw Hill BookCo. Inc. New York.

23. Kala TC, Christaind RM, Bai NR 2011. Effect of Rhizobium inoculation on the growth and yield of Horsegram (Dolichos biIorus L). Plant Arch 11(1): 97-99.
24. Rather SA, Hussain MA and Sharma NL (2010). Effect of bio-fertilizers on growth, yield and economics of field pea (Pisum sativum L.). Int J Agri Sci 1(54): 65-66.

25. Erman M, Ari E, Togay $\mathrm{Y}$ and Cig F (2009a). Response of field pea (Pisum sativum sp Arvense L.) to Rhizobium inoculation and nitrogen application in Eastern Anotolia. J of Animal and Vet Adv 8(22): 612-616.

26. Mishra PK, Bish SC, Miishra S, Sclvakumar G, Bisht JK and Gupta HS (2012). Coinoculation of Rhizobium leguminosarum-Pr1 with a cold tolerant Pseudomonas spp. improves iron acquisition, nutrient uptake and growth of field pea (Pisum sativum L.). J Plant Nutri 35(33): 243-256.

27. Namvar A and Sharifi RS (2011a). Phenological and morphological response of chickpea (Cicer arietinum L.) to symbiotic and mineral nitrogen fertilization. Zemd Agric. 98(2): 121-130.

28. Namvar A, Sharifi RS and Khandan T (2011b). Growth analysis and yield of chickpea (Cicer arietinum L.) in relation to organic and inorganic nitrogen fertilization. Ekolo. 57(3): 97-108.

29. Begum, AA, Leibovitch S, Migner $P$ and Zhang F (2001). Inoculation of pea (Pisum sativum L.) by Rhizobium legumiiwsarum bv. viceae pre-incubated with naringenin and hesperetin or application of naringenin and hesperetin directly into soil increased pea nodulation under short season conditions. Plant Soil 237(66): 71-80.

30. Maleki AM, Poumajaf, Naseri R and Rashnavadi R (2014). Effect of supplemental irrigation, Nitrogen chemical fertilizer, and Inoculation with Rhizobium bacteria on grain yield and its components of chickpea (Cicer arietinum L.) under rainfed conditions. Int J Agric Biosys Sci Engin 8(2): 88-92. 
31. Geneva M, Zehirov G, Djonova E, Kaloyanova N, Georgiev G and Stancheva I (2006). The effect of inoculation of Pea plants with mycorrhizal fungi and Rhizobium on nitrogen and phosphorus assimilation. Plant Soil Environ 52(44): 435-440.

32. Solaiman ARM and Rabbani MG (2006). Effects of Rhizobium inoculant, compost and nitrogen on nodulation, growth and yield of pea. Korean J Crop Sci 51(6): 534-538.

33. Ahmed R, Solaiman ARM, Haider NK, Siddiky MA and Islam MS (2007). Effect of inoculation methods of rhizobium on yield attributes yield and protein content in seed of Pea. $J$ Soil Nature 1(3): 30-35.

34. Zahir ZA, Yasin HM, Naveed M, Anjum MA and Khalid M (2010). L-tryptophan application enhances the effectiveness of rhizobium inoculation for improving growth and yield of mungbean (Vigna radiata L.). Pak J Bot 42(3): 1771-1780.

35. Shaharoona B, Jamro GM, Zahir ZA, Arshad M and Memon K S (2007a). Effectiveness of various Pseudomonas spp. and Burkholderia caryophylli containing ACC-deaminase for improving growth and yield of wheat (Triticum aestivum L.). J Microbiol Biotechnol 17(8): 1300-1307. 